\title{
KONDISI SOSIAL EKONOMI NELAYAN TANGKAP DI KABUPATEN KOLAKA
}

\author{
Ashabul Fahrozi Mujaddid \\ Universitas Indonesia, ashabul.fm@gmail.com \\ Fentiny Nugroho \\ Universitas Indonesia, fentiny2015@gmail.com
}

\begin{abstract}
The socio-economic conditions of fishermen in Kolaka Regency describe the identity and characteristics of fishermen, as well as ownership of assets owned as capital in developing capacity. They work as fishermen on the Bagan Ship which operates for a period of 3 to 4 months at sea. The purpose of this study was to describe the socio-economic conditions of fishermen in Kolaka Regency. The research was carried out using qualitative methods with descriptive types. In-depth interviews were conducted using a purposive sampling technique on the criteria of fishing fishermen, owners of Bagan Apung and fishing laborers as many as 9 fishermen, and the local government as many as 2 people. The results showed that the socio-economic conditions of fishermen were described by several components. First, the identity of the fisherman who owns the Bagan ship has the commercial fisher, the fisherman who owns the motorboat has the post peasant fisher, and the fishing worker has the peasant fisher. Second, fishermen have assets that are used in their work such as operational vessels and fishing equipment as physical capital, work skills as fishermen and management of fishing as human capital, utilize fishermen groups as social capital, and fishermen's economic capital is described as financial asset management.
\end{abstract}

Keywords:

Socioeconomic condition, fishermen, fishermen's capitals

\begin{abstract}
Abstrak
Kondisi sosial ekonomi para nelayan di Kabupaten Kolaka menggambarkan identitas dan karakteristik nelayan, serta kepemilikan aset yang dimiliki sebagai modal dalam mengembangkan kapasitas. Mereka bekerja sebagai nelayan pada Kapal Bagan yang beroperasi pada kurun waktu 3 hingga 4 bulan di laut. Tujuan penelitian ini adalah mendeskripsikan kondisi sosial ekonomi nelayan tangkap di Kabupaten Kolaka. Penelitian dilaksanakan dengan menggunakan metode kualitatif dengan jenis deskriptif. Wawancara mendalam dilakukan dengan teknik purposive sampling pada kriteria nelayan tangkap pemilik Bagan Apung dan buruh nelayan sebanyak 9 orang nelayan, serta pemerintah setempat sebanyak 2 orang. Hasil penelitian menunjukkan kondisi sosial ekonomi nelayan dideskripsikan oleh beberapa komponen. Pertama, identitas nelayan pemilik kapal bagan memiliki karakteristik sebagai commercial fisher pada usaha komersial, nelayan pemilik kapal motor memiliki karakteristik sebagai post peasant fisher, dan buruh nelayan memiliki karakteristik sebagai peasant fisher. Kedua, nelayan memiliki aset yang digunakan dalam bekerja seperti kapal operasional dan alatalat penangkapan ikan sebagai modal fisik, keterampilan kerja sebagai nelayan dan manajemen penangkapan ikan sebagai modal manusia, memanfaatkan kelompok nelayan sebagai modal sosial, dan modal ekonomi nelayan dideskripsikan dengan pengelolaan aset finansial.
\end{abstract}

Kata Kunci:

Kondisi Sosial Ekonomi, Nelayan, Modal, Nelayan 


\section{PENDAHULUAN}

Nelayan adalah individu/kelompok yang mata pencahariannya melakukan penangkapan ikan yang melibatkan tiga komponen utama, yaitu sumber daya manusia, unit penangkapan ikan, dan sumber daya ikan (Undang-Undang No 45 Tahun 2009 tentang Perikanan). Nelayan kecil bermodalkan tenaga dan peralatan penangkapan ikan sederhana, berpendidikan rendah, minim pengetahuan dan informasi, menjadi perasan tengkulak cukup besar dalam kehidupan sosial ekonomi mereka, baik dalam kegiatan produksi, pemasaran, bahkan dalam pemenuhan kebutuhan sehari-hari. Kusnadi (2003) menjelaskan bahwa kemiskinan yang terjadi pada masyarakat nelayan bukanlah suatu independen, melainkan akibat kebijakan masa lalu yang terlalu terkonsentrasi pada pembangunan wilayah darat (maritime orientation) sehingga menjadikan kelautan dan perikanan sebagai sektor pinggiran.

Salah satu Provinsi di Indonesia yang memiliki potensi kelautan dan perikanan yang cukup besar adalah Provinsi Sulawesi Tenggara yang terletak di Jazirah Tenggara Pulau Sulawesi yang wilayahnya meliputi daratan dan kepulauan. Wilayah daratan Sulawesi Tenggara mempunyai luas $38.140 \mathrm{~km} 2$ atau 3.814.000 ha sedangkan wilayah perairan (laut) seluas $110.000 \mathrm{~km} 2$ atau 11.000.000 ha. Dengan wilayah lautan yang lebih luas maka kegiatan usaha perikanan menjadi salah satu faktor yang memiliki kontribusi cukup besar terhadap kinerja sektor perikanan (Data Kelautan dan Perikanan Dalam Angka 2018).

Sebagaimana lazimnya di perairan laut tropis, di wilayah perairan laut Sulawesi Tenggara juga terdapat jenis ikan yang cukup banyak. Antara lain ikan yang dominan adalah ikan tuna, ikan cakalang, ikan teri, ikan ekor kuning, ikan kerapu, ikan beronang, ikan kembung, udang, Teristimewa jenis ikan ekor kuning, ikan kerapu dan ikan beronang (jenis ikan karang). Namun demikian, berbagai potensi perikanan tersebut masih dikelola dengan cara yang tradisional melalui penangkapan/ perikanan tangkap. Model penangkapan secara tradisional tersebut antara lain sangat dipengaruhi oleh kondisi cuaca yang ditandai dengan tingginya gelombang di laut sekitar Sulawesi Tenggara.

Kabupaten Kolaka merupakan salah satu kabupaten yang memiliki pesisir pantai di Sulawesi Tengara selain Kabupaten Bombana, Wakatobi, Kolaka Utara, Konawe Selatan, Konawe Utara, Buton Utara, Kolaka Timur, Konawe Kepulauan, Buton Tengah, Buton Selatan dan Muna Barat. Kabupaten Kolaka terdiri dari 12 Kecamatan, dimana 6 (enam) Kecamatan yaitu Latambaga, Watubangga, Toari, Pomalaa, Wolo, dan Samaturu merupakan Kecamatan di Wilayah pesisir paling berpotensi sebagai penghasil perikanan laut, dimana penduduknya banyak berstatus sebagai nelayan tangkap.

Dapat diketahui bahwa jumlah nelayan terbanyak ada di Kecamatan Latambaga, Kabupaten Kolaka dengan jumlah 1.798 (Jiwa). Jumlah setiap anggota keluarga nelayan sebanyak 5-7 orang dengan pendapatan rata-rata perbulan sekitar Rp. 1.200.000/ bulannya. Jika dilihat dari Penghasilan tersebut, dalam memenuhi kebutuhan pokok seperti sandang, pangan, kesehatan, pendidikan dan transportasi sangat berat. Selain itu, rendahnya sumber daya manusia (SDM) dan peralatan yang digunakan nelayan 
tangkap berpengaruh pada cara menangkap ikan (BPS Kolaka, 2016).

Kabupaten Kolaka memiliki pelabuhan dan tempat pelelangan ikan (TPI) yang berada tepat di Kecamatan Latambaga, sehingga wilayah ini berfungsi sebagai salah satu pemasok utama distribusi pasar ikan di Kabupaten Kolaka. Dari hasil wawancara dengan pemerintah dinas perikanan Kabupaten Kolaka, para nelayan seharusnya memiliki penghasilan yang mencukupi karena dinilai sebagai pemasok utama distribusi pasar ikan. Namun dilihat dari ekonominya, nelayan yang ada di daerah tersebut masih ada yang berada dikategori miskin, dikarenakan kurang mempunyai kemampuan dalam mengelola keuangan. Oleh karena itu, penghasilan yang didapatkan dalam sehari setelah berlayar langsung digunakan/habis.

Beberapa penelitian terdahulu terkait nelayan banyak membahas tentang kualitas hidup nelayan oleh MacHado dan Piccolo (2018), perilaku nelayan (Nguyen dan Leung, 2009), nelayan rentan miskin oleh Retnowati (2011), strategi bertahan hidup nelayan oleh Azizah (2019), dan kondisi sosial ekonomi nelayan oleh (Deshinta, 2014).

Aspek sosial ekonomi dalam mengembangkan kapasitas masih kurang difokuskan oleh peneliti-peneliti tersebut. Selain itu, penelitian diatas tidak begitu membahas tentang nelayan kondisi sosial ekonomi nelayan tangkap yang bekerja di kapal Bagan Apung. Oleh karena itu peneliti tertarik meneliti terkait Kondisi Sosial Ekonomi Nelayan Tangkap di Kabupaten Kolaka.

\section{METODE PENELITIAN}

Penelitian ini menggunakan metode kualitatif. dimana penelitian ini mengutamakan proses dan mengungkapkan kondisi sosial dan ekonomi. Pendekatan ini menggambarkan kondisi sosial ekonomi nelayan tangkap di Kabupaten Kolaka dengan berbagai cara yang dilakukan dalam menghadapi permasalahan penangkapan ikan dan kebutuhan mereka. Pendekatan kualitatif merupakan upaya menggali informasi secara luas daripara informan dalam setting yang alami.

Jenis penelitian ini adalah penelitian Deskriptif. Neuman (2014) menjelaskan bahwa penelitian deskriptif bertujuan untuk memberikan gambaran dengan menggunakan kata-kata dan angka serta untuk menyajikan profil (persoalan), klasifikasi jenis, atau garis besar tahapan penelitian. Terkait hal tersebut, jenis penelitian deskriptif akan menggambarkan situasi, penataan sosial serta hubungan dari tujuan penelitian ini. Penelitian ini mendekripsikan bagaimana kondisi sosial ekonomi nelayan tangkap di Kabupaten Kolaka.

Teknik pemilihan informan yang digunakan adalah purposive sampling yang untuk memilih sampel informan atas dasar pengetahuan tentang populasi, unsurunsurnya dan tujuan penelitian. Subyek penelitian yang akan diamati dipilih berdasarkan penilaian peneliti tentang informan yang paling banyak berguna dalam penelitian atau representatif (Babbie, 2014). Terkait hal tersebut, informan yang diwawancarai berdasarkan kriteria informan sebagai berikut :

1. 9 orang nelayan tangkap bagan apung (pemilik bagan apung, pemilik kapal \& buruh nelayan) Kelurahan Kolakaasi, berperan sebagai nelayan yang sudah lama 
bekerja sebagai nelayan atau yang keturunanya bekerja sebagai nelayan

2. 2 orang pemerintah Kab. Kolaka, yaitu pemerintah Dinas Perikanan Kabupaten Kolaka dan pemerintah wilayah Tempat Pelelangan Ikan, berperan sebagai stakeholder pembuat kebijakan dan aturan bagi nelayan tangkap.

\section{HASIL DAN PEMBAHASAN}

Bekerja sebagai nelayan di laut merupakan salah satu mata pencaharian utama masyarakat pesisir yang berada di Kabupaten Kolaka. Nelayan yang melakukan aktivitas penangkapan hasil melaut di wilayah Kolaka terbagi dalam beberapa komunitas. Diantaranya adalah komunitas nelayan tangkap lepas pantai, nelayan tangkap pesisir, nelayan pukat, dan nelayan tangkap bagan apung. Penelitian ini menggambarkan secara khusus pada kondisi sosial ekonomi nelayan tangkap bagan apung. Kondisi sosial mendeskripsikan tentang identitas dan karakteristik nelayan, serta segala aktivitas nelayan pada saat bekerja, serta aktivitas saat berada di lingkungan masyarakat. Kondisi ekonomi menggambarkan situasi perekonomian nelayan dan modal yang dimiliki untuk memenuhi kebutuhan.

1. Identitas dan Karakteristik Nelayan

Operasional penangkapan ikan dan hasil laut lainnya dengan menggunakan bagan tangkap apung dilakukan oleh nelayan-nelayan pemilik bagan, nelayan pemilik kapal, dan buruh nelayan. Ratarata nelayan memiliki latar belakang menjadi nelayan karena keterampilan kerja yang dimiliki sesuai dengan kebiasaan dan turunan orang tua. Identitas dan karakteristik nelayan terdiri dari nelayan pemilik kapal Bagan, nelayan pemilik kapal Motor dan buruh nelayan.
Nelayan pemilik kapal bagan apung memiliki usaha komersial karena statusnya sebagai pemilik kapal dan mampu mengatur manajemen operasional kegiatan penangkapan hasil laut dan mengatur pola kerja anak buah kapal (ABK) di lingkungan operasional/ area tangkap. Satria (2015) menggambarkan tipologi penggolongan nelayan. Salah satunya adalah nelayan yang memiliki usaha komersial dengan hirearki pemilik kapal dan memiliki anak buah kapal, serta kemampuan manajemen yang heterogen. Pemilik kapal bagan apung dapat memperoleh hasil laut dengan pemasaran siklus lokal, pasar domestik hingga ekspor. Pemasaran lokal dilakukan dengan transaksi jual beli ikan, cumi-cumi, bibit ikan atau umpan, dan tangkapan lainnya pada saat beroperasi di tengah laut dan pasar ikan di darat. Pemasaran domestik dilakukan dengan pengantaran luar kota, dan penjualan hasil laut kepada pengepul ikan yang berorientasi ekspor melalui mitra kerja.

Selanjutnya adalah pemilik kapal dengan mesin motor tempel. Kapal yang dimiliki digunakan untuk akomodasi pekerja bagan apung dan membantu membawa kapal bagan ke wilayah penangkapan (fishing ground) dan kembali ke daratan. Hasil wawancara menunjukkan bahwa pemilik kapal angkut juga dulunya memiliki latar belakang sebagai buruh nelayan dan kemudian berupaya menjadi pemilik kapal. Manajemen operasional kepemilikan kapal penunjang dilakukan dengan sistem sewa. Berdasarkan kondisi tersebut, Satria (2015) juga mengemukakan bahwa nelayan berupaya untuk meningkatkan potensi yang dimiliki karena perkembangan motorisasi perikanan yang menjadikan nelayan peasant fisher atau tradisional menjadi 
post peasant fisher. Kepemilikan kapal yang dimiliki oleh informan sebagai post peasant fisher digunakan untuk akomodasi operasional kerja nelayan bagan apung.

Adapun kondisi sosial buruh nelayan menjelaskan latar belakang menjadi buruh nelayan karena membantu pekerjaan orang tua, kemudian menjadi anak buah kapal (ABK) di salah satu bagan apung yang dimiliki oleh keluarga. Mereka bekerja sebagai buruh angkut ikan, teknisi, penarik jaring dan kemampuan lainnya untuk memperoleh hasil tangkapan laut yang lebih banyak. Buruh nelayan atau ABK memiliki latar belakang sebagai nelayan subsistence fisher. Charles mengemukakan bahwa nelayan melakukan aktivitas penangkapan ikan untuk kebutuhan konsumsi sehari-hari (Satria, 2015). Hal ini juga dijelaskan sebagai nelayan tradisional atau peasant fisher. Nelayan tradisional berorientasi pada pemenuhan kebutuhan pokok sehari-hari dan bukan untuk diinvestasikan. Kemampuan melaut digunakan tidak untuk menangkap ikan dengan kepemilikan kapal pribadi, melainkan membantu pemilik kapal dalam usaha penangkapan hasil laut di kapal bagan apung dengan manajemen usaha yang lebih besar dan modern serta memperoleh penghasilan yang lebih baik.

2. Kepemilikan aset nelayan

Aset nelayan merupakan suatu modal yang dimanfaatkan dalam bekerja di laut dan di darat. Modal tersebut dapat membantu pencapaian nelayan dalam memenuhi kebutuhan dasar. Gambaran modal atau aset pada nelayan tangkap bagan apung merupakan gambaran kondisi sosial ekonomi nelayan yang mendukung pengembangan kapasitas nelayan untuk melakukan aktivitas ekonomi. Aset nelayan digambarkan pada modal nelayan sebagai modal fisik, modal manusia, modal sosial, dan modal ekonomi.

Pertama, modal fisik merupakan aset dasar yang melekat pada masyarakat. Green dan Haines (2002) menjelaskan bahwa beberapa bentuk modal fisik adalah aksesibilitas dan tempat-tempat dimana orang dapat bekerja. Berdasarkan pernyataan tersebut, kepemilikan aset nelayan sebagai modal fisik adalah kepemilikan kapal bagan apung sebagai kapal operasional kerja, kapal motor sebagai kapal akomodasi, dan alat-alat tangkap nelayan yang digunakan dalam melaut. Kapal yang digunakan dalam mencari ikan dan hasil laut lainnya adalah kapal bagan apung seluas $14 \mathrm{~m}$ x $14 \mathrm{~m}$ hingga $20 \mathrm{~m}$ x $20 \mathrm{~m}$ yang beroperasi selama 3 hingga 4 bulan di tengah laut untuk naungan penangkapan ikan-ikan pelagis, cumi-cumi dan ikan-ikan jenis lainnya yang bernilai ekonomis. Selain itu, nelayan juga memanfaatkan kapal motor sebagai kapal akomodasi untuk pengangkutan barang, hasil laut, dan para pekerja. Kapal tersebut digunakan dengan sistem sewa untuk mendampingi kapal bagan apung dalam beroperasi di tengah laut. Kepemilikan aset nelayan berupa kapal bagan apung, kapal motor, dan alat tangkap nelayan merupakan gambaran status sosial nelayan terhadap aset fisik dalam kepemilikan pribadi yang dimanfaatkan untuk memperoleh pendapatan yang efektif dari partisipasi anggota kelompok (Kaare, dalam Sumardi, 2009). Partisipasi anggota kelompok yang memanfaatkan aset tersebut adalah para nelayan yang bekerja di kapal bagan apung.

Kedua, modal manusia menurut Green dan Haines (2002) merupakan sumber daya manusia yang berupa berupa kemampuan dan keterampilan pekerja 
yang berpengaruh terhadap produktivitas mereka. Terkait hal tersebut, para pemilik kapal mengikutsertakan para ABK yang terampil dan memiliki komitmen dalam melaut sebagai aktivitas perekonomian utama mereka. Pemilik kapal juga memiliki keterampilan dalam manajemen atau kontrol terhadap nelayan-nelayan yang bekerja di kapalnya. Adapun keterampilan dari buruh nelayan yaitu dengan memanfaatkan keterampilan fisik pada diri secara personal dalam, menangkap ikan, persiapan alat-alat penangkapan, perawatan kapal, dan membantu transaksi jual beli ikan. Ketika berada di darat, buruh nelayan juga melakukan pekerjaan lainnya seperti berkebun, menjadi tukang bangunan, dan tukang ojek untuk membantu memenuhi kebutuhan hidup mereka.

Ketiga, modal sosial nelayan. Adi (2013) menjelaskan bahwa modal sosial merupakan suatu norma yang dapat mengatur perilaku masyarakat, kepercayaan dan jaringan antar warga ataupun kelompok. Hasil wawancara menunjukkan bahwa terdapat kelompok nelayan tangkap bagan apung yang menjadi organisasi swadaya dalam hal dukungan pekerjaan dan membantu pemecahan masalah. Adanya hubungan kelompok nelayan yang erat dalam swadaya merupakan modal sosial sebagai bonding capital yang mengikat anggotaanggota masyarakat dalam suatu kelompok atau komunitas.

Keempat, modal ekonomi nelayan. Dalam melaksanakan aktivitas ekonomi sebagai nelayan tangkap bagan apung, mereka memperoleh penghasilan sesuai dengan pencapaian target pemasaran. Pendapatan yang diperoleh pemilik bagan berbeda dengan upah para buruh. Namun, pengelolaan pendapatan hasil laut, diatur oleh pemilik kapal untuk pembagian upah anak buah kapal/buruh nelayan, perawatan kapal, modal, dan perencanaan lainnya untuk aktivitas penangkapan ikan selanjutnya. Upah yang diperoleh buruh nelayan bersifat harian dan mingguan. Selain dari penghasilan melaut, nelayan juga berupaya untuk memperoleh penghasilan dari pekerjaan lain dan bantuan finansial lainnya untuk pemenuhan kebutuhan hidup.

Pendapatan yang dimiliki oleh buruh nelayan berada dikisaran $\mathrm{Rp}$. 150.000,- hingga Rp. 200.000,- untuk sekali melaut yang bila dirata-ratakan dalam perbulannya mencapai 1,5 juta hingga 2 juta rupiah apabila kondisi cuaca sedang baik dan tangkapan. Dapat dikatakan bahwa klaster buruh nelayan di Kolaka sesuai dengan penghasilan yang didapatkan berada pada tingkatan status ekonomi rendah.

Adapun penghasilan yang didapatkan oleh pemilik kapal tempel di Kabupaten Kolaka berada dikisaran Rp. 4 juta hingga Rp. 5 juta untuk biaya sewa satu kapal yang dimiliki dalam sebulan. Kondisi tersebut memungkinkan dirinya untuk memenuhi kebutuhan sehari-hari dan digunakan untuk menabung. Oleh karena itu, dapat dikatakan bahwa pemilik kapal tempel berada pada tingkatan status ekonomi sedang, dimana golongan orangorang yang dapat memenuhi kebutuhan primer dan sekunder yang kedua, yaitu kebutuhan tambahan.

Selanjutnya, yaitu nelayan pemilik bagan apung dalam hal ini dapat dikatakan berada pada tingkatan status ekonomi tinggi diwilayah Kolaka. Dimana jumlah pendapatan yang diterima dari hasil laut oleh pemilik bagan berada di angka Rp. 15 juta hingga Rp. 20 juta dalam sebulan. Sesorang yang berada pada tingkatan 
status ekonomi tinggi merupakan seseorang yang mampu memenuhi kebutuhan primer dan sekunder pertama yaitu berupa barang mewah. Pada temuan lapangan menyatakan bahwa dari hasil melaut pemilik bagan apung telah mampu membeli sejumlah mobil yang dia gunakan untuk keperluan pribadi dan operasional usahanya dalam bidang perikanan.

Penghasilan nelayan selain dari melaut juga dapat menjadi faktor penentu dalam menentukan kondisi sosial ekonomi. Buruh nelayan sebagai orang yang berada dalam status ekonomi rendah memiliki kekurangan dimana dirinya tidak bisa mengakses pendapatan lain selain dari hasil melaut dikarenakan tidak adanya keterampilan yang ia miliki diluar dari pekerjaannya sebagai buruh nelayan. Bebanding terbalik buruh nelayan, pemilik bagan apung yang memiliki keleluasaan modal dan kejeliaan meliat peluang usaha lain dibidang perikanan lain seperti berjualan es balok sehingga mampu meningkatkan pendapatan keluarganya selain dari hasil melaut.

\section{KESIMPULAN}

Kondisi sosial ekonomi para nelayan yang bekerja di Kapal Bagan Kabupaten Kolaka menggambarkan identitas dan karakteristik, serta kepemilikan dan pemanfaatan aset sebagai modal dalam mengembangkan kapasitas. Beberapa hal yang dapat disimpulkan dari hasil analisa penelitian terhadap kondisi sosial ekonomi nelayan adalah:

1. Identitas nelayan pemilik kapal bagan memiliki karakteristik sebagai commercial fisher pada usaha komersial karena status pemilik kapal mampu mengatur manajemen operasional kegiatan penangkapan ikan dan pola kerja anak buah kapal. Selain itu, nelayan pemilik juga memiliki strategi pemasaran hasil laut pada siklus pemasaran lokal, domestik, hingga ekspor. Adapun nelayan pemilik kapal motor memiliki karakteristik sebagai post peasant fisher dengan usaha post tradisional karena memanfaatkan aset yang dimiliki berdasarkan perkembangan motorisasi perikanan dengan mesin tempel untuk dioperasikan sebagai bantuan akomodasi operasional kerja nelayan kapal bagan apung. Selanjutnya, identitas buruh nelayan atau anak buah kapal memiiki karakteristik sebagai peasant fisher atau subsistence fisher. Buruh nelayan berorientasi pada pemenuhan kebutuhan pokok sehari-hari dan tidak memiliki perencanaan untuk investasi kerja.

2. Kepemilikan aset nelayan merupakan interpretasi dari modal fisik, modal manusia, modal sosial, dan modal ekonomi nelayan. Aset fisik nelayan menggambarkan status sosial kepemilikan aset kapal bagan apung, kapal motor tempel, dan alat-alat penangkapan hasil laut yang dimanfaatkan untuk memperoleh pendapatan yang efektif dari partisipasi nelayan. Modal manusia merupakan sumber daya manusia dengan keterampilan kerja yang mumpuni dan produktif sebagai nelayan. Pemilik kapal berkontribusi sebagai manajer operasional kerja, sedangkan anak buah kapal/buruh nelayan berkontribusi untuk memanfaatkan segala keterampilan fisik dalam melakukan penangkapan hasil laut, perawatan, dan membantu penjualan ikan. Selanjutnya adalah modal sosial yaitu adanya kelompok nelayan dengan hubungan bonding capital untuk swadaya nelayan dalam pengambilan keputusan, peningkatan kapasitas kerja dan pemecahan masalah bersama. Adapun Modal ekonomi nelayan merupakan segala 
upaya dalam mengelola dan meningkatkan aset finansial yang diperoleh dari penghasilan dari melaut, penghasilan selain melaut, dan bantuan pemerintah.

\section{DAFTAR REFERENSI}

Adi, I. R. (2013). Intervensi komunitas dan pengembangan masyarakat (Sebagai upaya pemberdayaan masyarakat) ( $2^{\text {nd }}$ ed). Jakarta: PT Raja Grafindo Persada.

Azizah. (2019), Strategi bertahan hidup nelayan-nelayan kecil Desa Batu Ampar, Kecamatan Palmatak, Kabupaten Anambas. Jurnal Ilmu Kesejahteraan Sosial, 20 (2): 8193.

Babbie, E. (2014). The basic of social reasearch (6th ed.). Canada: Wadsworth Cengange Learning.

Badan Pusat Statistik Kabupaten Kolaka. (2016). Kabupaten Kolaka dalam Angka 2017. Kolaka: BPS Kabupaten Kolaka.

Deshinta, V. (2014). Kondisi sosial ekonomi dan pemberdayaan nelayan tangkap Kota Tegal, Jawa Tengah. Jurnal, 1(1): 18-25.

Green, G.P., \& Haines, A. (2016). Asset building and community development. Thousand Oaks. California: SAGE Publications.

Kementerian Kelautan dan Perikanan. (2018). Kelautan dan Perikanan dalam Angka 2018. Jakarta : Pusat Data, Statistik dan Informasi Kementrian Kelauatan dan Perikanan (KKP).

Kusnadi. 2003. Akar Kemiskinan Nelayan Kondisi Sosial Ekonomi Nelayan di Indonesia. PT LKis Pelangi Aksara: Yokyakarta
MacHado., \& Piccolo. (2018). quality of living conditions and quality of life of fishermen from pereque, Brazil: a qualitative-quantitative approach. Jurnal, 3 (2): 10-21.

Neuman, W.L. (2014). Metode penelitian sosial: Pendekatan kualitatif dan kuantitatif (7th ed.). Jakarta: PT Indeks.

Nguyen., \& Leung. (2009). Do fishermen have different attitudes toward risk? an application of prospect theory to the study of vietnamese fishermen. Jurnal, 2 (3): 35-48.

Retnowati. (2011). Nelayan Indonesia dalam pusaran kemiskinan structural (perspektif sosial, ekonomi dan hukum). Jurnal, 4 (5): 13-24.

Satria, A \& Helmi, A. (2015). Strategi adaptasi nelayan terhadap perubahan ekologi. Sosial Humaniora, Vol. 16 No.1 , 68-78.

Sumardi, M., \& Hans. (2009). Kemiskinan dan kebutuhan pokok.Jakarta: CV. Rajawali.

Undang-undang Republik Indonesia Nomor 45 tahun 2009 tentang perikanan, pembangunan perikanan di Indonesia. 